\title{
REDUCING THE HARM IN RAIL CRASHES: ANALYSIS OF INJURY MECHANISMS AND MITIGATION STRATEGIES
}

\author{
Bruce Wilson \\ David Tyrell \\ Volpe National Transportation Systems Center \\ United States Department of Transportation \\ Cambridge, Massachusetts, USA
}

\begin{abstract}
Twenty-three commuter and inter-city passenger train accidents, which occurred over the past twenty years, have been analyzed. The analysis has assessed the potential effectiveness of various injury mitigation strategies. The strategies with the greatest potential to increase passenger safety are interior occupant protection, coupler integrity, end structure integrity, side structure integrity, and glazing system integrity. We recommend that these strategies be researched further.

Three types of accidents were analyzed: train-to-train collisions, derailments, and grade-crossing collisions. Train-totrain collisions include the commuter train-freight train collision in Chatsworth, California on September 12, 2008. In Chatsworth a commuter train collided with a freight train at a closing speed of $\sim 80 \mathrm{mph}$, fatally injuring twenty-five people and injuring more than 100 others. Derailments include the commuter train derailment in Spuyten Duyvil, New York on December 1, 2013, fatally injuring four people and injuring more than fifty others. Grade-crossing accidents include the commuter-SUV collision in Valhalla, New York on February 3, 2015, which resulted in six fatally injured people, including the SUV driver, and thirteen severely injured people.

Four categories of mitigation strategies were considered: train crashworthiness, wayside structure crashworthiness, fire safety, and emergency preparedness. Within each of these categories are equipment features, which may potentially be modified to further mitigate injuries. The features are simple noun phrases, e.g., "floor strength," implying that the floor strength should be increased. Train crashworthiness includes features such as end strength, floor strength, coupler separation, and numerous others. Wayside structure crashworthiness includes features such as frangible catenary poles and third rail
\end{abstract}

end caps. Fire safety includes train interior and train exterior features for minimizing the potential for fire and for reducing the rate at which fire might spread. Emergency preparedness includes features for emergency egress, access, lighting, signage, and on-board equipment, such as fire extinguishers.

Overall, rail passenger travel has a high level of safety, and passenger train accidents are rare events. The numbers are low for expected casualties per passenger-mile and casualties per passenger-trip. A high level of safety, however, does not mean efforts to improve it should cease. But it does mean that crashes are rare events. Rare events in complex systems are notoriously difficult to analyze with confidence. There are too few accidents to provide the data needed for even a moderate degree of mathematical confidence in statistical analysis. Analyses of similar data in medical and scientific fields have been shown to be prone to the biases of the researchers, sometimes in subtle and difficult-to-detect ways. As a means of coping with the sparse data and potential biases, the goal has been to evaluate the accidents transparently and comprehensively. This approach allows a wide audience to understand how injuries and fatalities occur in passenger train accidents and, most importantly, allows us to prioritize mitigation strategies for research.

\section{INTRODUCTION}

The Federal Railroad Administration directs research to advance technologies for rail equipment crashworthiness and facilitate their implementation in the railroad industry. Research activities include failure analyses informed by accident investigations, identifying engineering improvements to mitigate the hazards, and aiding industry in implementation of those improvements. Figure 1 illustrates this research approach and the some of the results.

1

This material is declared a work of the U.S. Government and is not subject to copyright protection in the United States. Approved for public release; distribution is unlimited. 


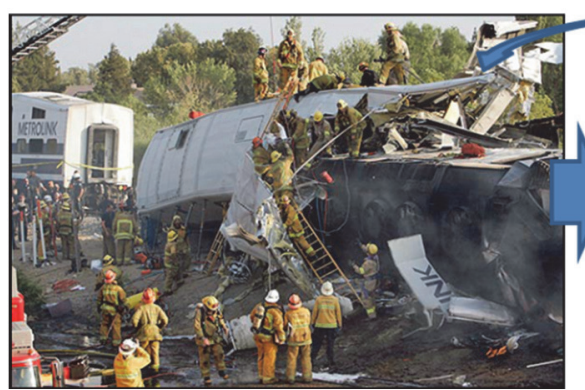

Accident Investigations and

Hazard Analysis

Activity: Evaluation of

current safety performance

Results: Recommendations

for improved safety

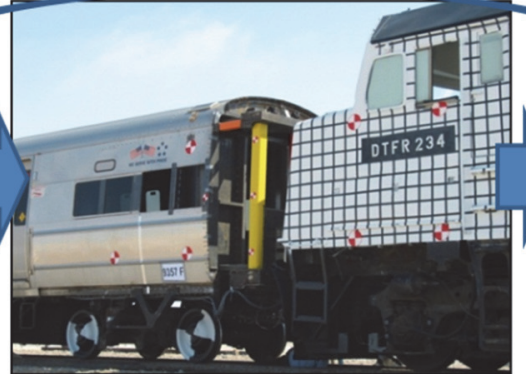

Engineering improvements

Activity: Computer models and tests used to develop improvements

Results: Proof-of-concept, industry demonstration

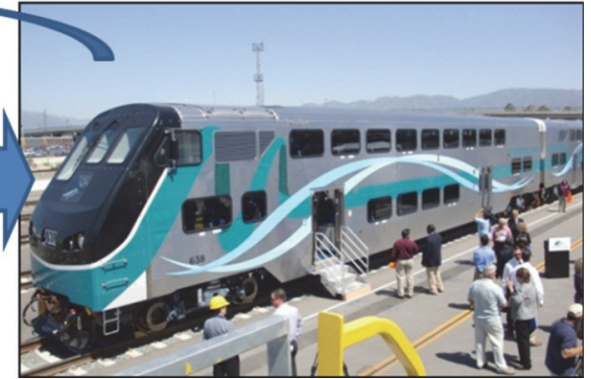

Implementation

Activity: Development of technical standards

Results: Application of advanced technologies and increased safety

FIGURE 1. Approach to engineering research on rail equipment crashworthiness.

As technological advances show promise for improved performance, activities can proceed in an evolutionary fashion, with continuous research leading to continuously improving standards and safer designs.

The passenger rail equipment crashworthiness research has gone through several phases as it has progressed. Past research focused principally on three topics: Crash Energy Management (CEM), with crush zones at the ends of passenger cars, cab car end frame integrity, and interior occupant protection at seats and tables. Current passenger rail equipment crashworthiness research encompasses five topic areas: glazing integrity, locomotive CEM features, diesel fuel tank integrity, measurement of improved table performance, and carbody side structure integrity. This paper discusses potential future research topics, based on review and analysis of past accident investigations.

\section{Accident Investigations}

When a severe passenger train accident occurs, the National Transportation Safety Board (NTSB) investigates it to determine probable cause. NTSB, while part of the federal government, is independent of the Executive Branch's department structure. With this independence, NTSB acts something like an public auditor of FRA and the rail industry, openly disseminating information on accidents as it conducts field investigations.

FRA, part of the U.S. Department of Transportation, has responsibility for safety oversight of the railroads operating on the general railroad system. FRA typically conducts two concurrent investigations of severe passenger train accidents: one to assure existing regulations were appropriately complied with and a second forensic investigation. The purpose of the forensic investigation is to estimate the sequence of events leading to injury and fatality. Information is gathered at the site of the accident and by interviewing the train crew, passengers, and emergency responders. This information is organized and synthesized in order to estimate the sequence of events and identify causal mechanisms of injury. The effectiveness of current crashworthiness, fire safety, and emergency preparedness regulations is evaluated and recommendations are provided for developing improved safety regulations.
The review and analysis of past passenger rail accidents presented in this paper uses information from both NTSB and FRA accident investigations.

\section{Past Research Activities}

FRA has continuously conducted research into passenger rail equipment crashworthiness since 1989. Interest in high speed passenger trains led to work on balancing accident survivability with accident avoidance [1]. This research brought to light accident conditions which are beyond the influence of train control systems. At grade-crossings and on rights-of way, highway vehicles can collide with trains. Train derailments can occur due to undetected track and equipment deficiencies. Even when Positive Train Control systems are fully in place, manual train operation will be allowed for low train speeds [2]. Improper manual operation potentially can allow two trains to be on the same track, each travelling toward the other at $20 \mathrm{mph}$.

In the early 1990s, Amtrak's interest in high speed service mixed with conventional intercity, commuter, and freight service - from Boston to New York to Washington spurred research into CEM. CEM builds on previously developed rail equipment crashworthiness technology and manages the load path between cars during a collision. With CEM, vertical and lateral loads that may lead to override and train lateral buckling are minimized. In France, the TGV-2N had been designed with CEM features [3]. In England, then-recent accidents had led to fullscale train-totrain collision tests, including tests of equipment with CEM features [4]. In Japan, research had been conducted into the physics of CEM [5]. Building on world-wide engineering efforts, further engineering research was conducted [6] and a specification was developed for Amtrak's high speed train. This specification later formed the basis for the Tier II crashworthiness regulations [7]. Subsequently, research was conducted on applying CEM to conventional speed passenger equipment. From 1999 to 2005, FRA conducted a series of six impact tests to assess the crashworthiness of rail passenger equipment, both conventional and that with CEM features [8]. The results showed that CEM features can improve crashworthiness significantly. The results of this research were used to specify the crashworthiness features of Metrolink's

This material is declared a work of the U.S. Government and is not subject to copyright protection in the United States. Approved for public release; distribution is unlimited. 
Guardian equipment [9] and are being used to develop alternative crashworthiness regulations for trainsets [10].

In parallel with the research on structural crashworthiness and CEM, research was conducted on interior occupant protection $[11,12]$. While structural crashworthiness focuses on preserving space for occupants to ride out an accident, occupant protection focuses on limiting forces imparted to occupants to survivable levels. Initially, this work addressed passengers seated in rows of seats, applying the strategy of compartmentalization. In accidents, rail equipment does not decelerate as rapidly as automobiles decelerate [13]. By limiting how far occupants can travel in the interior and by providing strategic padding, the forces imparted to a train passenger can be kept below the level of forces imparted to an automobile passenger. After the April 23, 2002 commuter train-to-freight train collision in Placentia, California, occupant protection research expanded to include tables [14]. The results of the FRA's occupant protection research have been used to develop FRA regulations for seat and table securement [7] and industry standards for occupants seated in rows and at tables $[15,16]$.

On January 18, 1993 two cab car-led commuter trains collided on a gauntlet bridge in Gary, Indiana [17]. Seven passengers were fatally injured. On gauntlet track, two parallel tracks partially overlap. Although they were travelling in opposing directions, the cab cars did not collide directly headon. Rather the cab cars collided corner-to-corner, with little engagement of the draft sills, the strong underframe structural element along the centerlines of the cars. Owing to the consequence of this accident and general concerns about cab car crashworthiness, the scope of structural crashworthiness research was expanded to include cab-car end-frame integrity [18]. The objective of this expanded research was to develop strategies for cab car integrated end frame designs, with strength commensurate with underframe strength. Shortly after this research started, passenger train collisions in Secaucus, NJ [19] and Silver Spring, MD [20] acted to increase urgency. FRA conducted a series of tests to assess the crashworthiness of cab car end frame elements, i.e., corner posts and collision posts [21]. The information developed from this research helped provide the technical basis for FRA's 2010 final rule on Front End Strength of Cab Cars and Multiple-Unit Locomotives [22]. The Bridgeport, CT commuter train accident was the first major accident involving equipment developed under the 2010 final rule on passenger-carrying locomotive cab end strength, cited above. The cab end performed as expected, and the corner posts on the non-cab end of the equipment also provided a level of protection against the side-swipe impact.

\section{Present Research Activities}

Current passenger rail equipment crashworthiness research is ongoing in five topic areas: locomotive CEM features, diesel fuel tank integrity, table compartmentalization, side structure integrity, and glazing integrity. The research on locomotive CEM features builds on cab and trailer car CEM research. Accidents with freight locomotives have also helped motivate this research [23]. Research on fuel tank integrity is principally motivated by increasing application of diesel-powered selfpropelled passenger rail equipment, such as DCTA, CMTA, TexRail, and SMART. Tests are ongoing of fuel tank puncture resistance [24], and tests are planned for locomotives equipped with CEM features [25]. For table compartmentalization, current research on occupant protection is aimed at developing improved instrumentation for measuring abdominal load [26]. This research is being conducted in cooperation with UK counterparts. Both the carbody side structure integrity research and the glazing integrity research [27] are being conducted in response to recent accidents, and also to help FRA respond to NTSB recommendations $[28,29]$. As part of the research on side structure integrity and glazing integrity, accident reviews are being conducted. The purpose of these reviews is to find similar accidents, with similar modes of injury.

The sidewall of an Amtrak train was breached in a gradecrossing accident in Lovelock, Nevada on June 24, 2011 [28]. A tandem tractor-trailer impacted the side of a double-deck passenger rail car at a speed of approximately $28 \mathrm{mph}$. Four passengers, a train crew member, and the tractor trailer driver were fatally injured. Ongoing review of similar accidents indicates that most sidewall impacts are either distributed over a large area, as when a car rolls over during a derailment, or raking along the side of the car, as when a train hits a highway vehicle at a grade-crossing and the highway vehicle pinwheels down the side of the train. Review results to date indicate that with distributed impacts current passenger rail equipment is effective in maintaining sidewall integrity, but with raking impacts there can be loss and penetration of survival volume.

In Spuyten Duyvil, New York on December 1, 2013, four passengers were fatally injured during a commuter train derailment [29]. All four fatalities were attributed to ejection through window openings. Results of the FRA's accident investigation indicate that the rubber gaskets holding the window panes in place were pulled out when the cars left the track and slid on their sides. The windows were pushed inside the cars, creating openings. Victims appear to have been pulled out when they contacted the ground through window openings, as the cars continued to slide. Nearly all of the polycarbonate window panes remained substantially intact, as did the car sidewalls. The mode of passenger ejection found in the Spuyten Duyvil investigation has also been experienced in other derailments, such as the Amtrak derailment in Crescent City, Florida, on April 18,2002 [30]. Windows have more often remained in place and contained occupants when cars have not slid on their sides for significant distances, as in the Amtrak derailment in Nodaway, Iowa on March 17, 2001 [31] and the Metrolink grade-crossing accident in Oxnard, California on February 24, 2015 [32].

\section{Planning Future Research Activities}

The accident reviews associated with the glazing integrity research and the side structure integrity research prompted a more broadly scoped review of past passenger train accidents. The purpose of this broader review is to identify if there are other passenger equipment features, in addition to glazing and side structure, which might be effective in mitigating accident consequences. The work described in this paper identifies the design changes associated with the greatest potential benefits, so that research related to these changes may be given priority.

\section{OVERVIEW OF METHODOLOGY}

Rail passenger travel has a high level of safety, and passenger train accidents are rare events. The numbers are low

This material is declared a work of the U.S. Government and is not subject to copyright protection in the United States. Approved for public release; distribution is unlimited. 
for expected casualties per passenger-mile and casualties per passenger-trip. Rare events in complex systems, such as passenger rail transportation systems, are notoriously difficult to analyze with confidence. There are too few accidents to provide the data needed for even a moderate degree of mathematical confidence in statistical analysis. Analyses of similar data in medical and scientific fields have been shown to be prone to the biases of the researchers, sometimes in subtle and difficult-todetect ways [33]. As a means of coping with the sparse data and potential biases, the work described here has evaluated 23 accidents transparently and comprehensively. This approach allows a wide audience to understand how injuries and fatalities occur in passenger train accidents and, most importantly, it allows rational prioritization of potential design changes for further research.

The research into identifying and ranking mitigation strategies began with a diverse and well-documented sample of 23 crashes. The crashes are listed in Appendix A in Table A1 (train to train), Table A2 (derailment), and Table A3 (grade crossing). For each crash, both documents and digital images are available. The documents include a combination of NTSB reports, FRA-sponsored accident forensic reports, and technical papers on crashworthiness analysis or crash reconstruction.

The reports and papers describe injuries and their mechanisms. These documents (less so for the NTSB reports) generally include material describing interior damage and the effect of the damage on passengers and crew. For example, reference [34] on the commuter train incident that occurred in Glendale, California on January 26, 2005 notes, "The largest loss of survival space occurred in car 625 of the southbound passenger train, where there was roughly 26 feet of crush at the front of the car and additional shearing at the trailing end. The front mezzanine level was lost entirely, along with its fifteen seats." There were seven fatalities in that car, all presumably caused by the loss of survival space. Knowledge of the injury mechanism allows us to postulate a design change that would have prevented or mitigated an injury.

The seven fatalities in the Glendale, CA crash, all with the same cause, could have been prevented or mitigated by a particular design change, improved end strength ("end strength" in Table 1), which would have improved occupant volume integrity. For this crash, end strength thus becomes a design change, one that would almost certainly have saved seven lives. The Glendale crash records also describe the passenger with the most serious injuries to have been likely seated in the area with the lost survival space. Thus the end-strength design change would also probably have mitigated the injuries of that passenger.

The approach applied in this work was to read reports and find descriptions of fatal and non-fatal injuries. For each description, a design change that could have prevented the injury was identified. These changes are described in Appendix B, in Table B1 - Table B5. The changes were entered into a database with fields for the crash name, the change category (e.g. "Emergency preparedness"), the change subcategory, the design change itself, a code for the change addressing a fatal injury, nonfatal injury, or a risk, and the confidence that the design change would indeed have the desired effect of mitigating or preventing the fatal or non-fatal injury or the risk. For the Glendale, CA design change discussed earlier, the entry includes the fields:

- Vehicle crashworthiness (category)

- Carbody integrity (subcategory)

- Increased end strength (design change)

- Fatality (what is being addressed)

- Almost certain (confidence that change would have desired effect)

\section{RESULTS}

From the 23 crashes reviewed, 139 design changes were identified and inserted into a database. From the database three cross tabulation tables were created: fatal injuries, non-fatal injuries, and risks. The table rows list the design changes and the columns the confidence that a given change would have the desired effect. Confidence choices include "almost certain," "probable," and "possible." Individual cells in the table contain counts (frequencies). For example, the design change "Compartmentalization" has five instances of "almost certain" confidence that it would have saved lives in five fatal crashes. The three cross tabulations help identify which design changes will likely have the most benefit, where a design change with large counts with a high confidence indicates a large potential benefit.

Table 1. Design changes for fatal injuries

\begin{tabular}{|l|l|l|l|l|}
\hline $\begin{array}{l}\text { Design } \\
\text { Change }\end{array}$ & $\begin{array}{l}\text { Almost } \\
\text { Certain }\end{array}$ & Probable & Possible & Total \\
\hline $\begin{array}{l}\text { Compartment- } \\
\text { alization }\end{array}$ & 5 & 1 & 0 & 6 \\
\hline $\begin{array}{l}\text { Coupler } \\
\text { separation }\end{array}$ & 0 & 3 & 2 & 5 \\
\hline $\begin{array}{l}\text { Crash energy } \\
\text { management }\end{array}$ & 5 & 0 & 0 & 5 \\
\hline End strength & 5 & 0 & 0 & 5 \\
\hline Side strength & 4 & 1 & 0 & 5 \\
\hline Windows & 4 & 0 & 0 & 4 \\
\hline Seats & 2 & 0 & 0 & 2 \\
\hline $\begin{array}{l}\text { Third rail end } \\
\text { cap }\end{array}$ & 1 & 0 & 0 & 1 \\
\hline Bulkheads & 1 & 0 & 0 & 1 \\
\hline $\begin{array}{l}\text { Catenary } \\
\text { poles }\end{array}$ & 0 & 1 & 0 & 1 \\
\hline Doors & 1 & 0 & 0 & 1 \\
\hline Egress & 0 & 1 & 0 & 1 \\
\hline $\begin{array}{l}\text { End frame } \\
\text { strength }\end{array}$ & 1 & 0 & 0 & 1 \\
\hline Interior & 0 & 1 & 0 & 1 \\
\hline Luggage rack & 0 & 1 & 0 & 1 \\
\hline $\begin{array}{l}\text { Panels and } \\
\text { flooring }\end{array}$ & 1 & 0 & 0 & 1 \\
\hline $\begin{array}{l}\text { Passenger } \\
\text { seats }\end{array}$ & 0 & 1 & 0 & 1 \\
\hline Tables & 1 & 0 & 0 & 1 \\
\hline \hline Total & $\mathbf{3 1}$ & $\mathbf{1 0}$ & $\mathbf{2}$ & $\mathbf{4 3}$ \\
\hline
\end{tabular}

Table 1 reports counts for design changes intended to address fatal injuries. Six design changes have total counts of

This material is declared a work of the U.S. Government and is not subject to copyright protection in the United States. Approved for public release; distribution is unlimited. 
four or greater. Compartmentalization is the design change with the highest total. This is due to high relative velocities between the passengers and forward areas of the trains, leading to numerous fatal injuries. Compartmentalization, keeping individual or groups of passengers in a smaller volume, would have arrested the motion of the passengers earlier in the crash and allowed them to decelerate more gradually with the car body rather than rapidly against the car body.

In Table 1 coupler separation, CEM, end strength, and side strength have the second highest total. The confidence that addressing coupler separation, however, would mitigate fatal injuries is either "probable" or "possible." This lower confidence is due to a longer chain of causal reasoning. As opposed to the single-step reasoning of compartmentalization, coupler separation's reasoning has multiple steps: "had the cars not uncoupled, they would likely have remained upright. Had they remained upright, the passenger would not have impacted the opposite wall." The more steps involved in the reasoning, the less confidence in the reasoning. Hence, the confidence in coupler separation is lower.

Table 2 tabulates design changes intended to address nonfatal injuries. Here compartmentalization, along with seats, also leads design changes. Many non-fatal injuries occurred when passengers hit the hard seat backs or tray tables in front of them. A modification to the seat backs, such as incorporating more energy absorbing materials, could have prevented such injuries. Luggage racks and tables also caused numerous non-fatal injuries.

Table 2. Design changes for non-fatal injuries

\begin{tabular}{|l|l|l|l|l|}
\hline $\begin{array}{l}\text { Design } \\
\text { change }\end{array}$ & $\begin{array}{l}\text { Almost } \\
\text { Certain }\end{array}$ & Probable & Possible & Total \\
\hline $\begin{array}{l}\text { Compartment- } \\
\text { alization }\end{array}$ & 12 & 2 & 0 & 14 \\
\hline Seats & 7 & 6 & 1 & 14 \\
\hline Luggage rack & 4 & 2 & 0 & 6 \\
\hline Tables & 4 & 1 & 0 & 5 \\
\hline $\begin{array}{l}\text { Coupler } \\
\text { separation }\end{array}$ & 0 & 2 & 2 & 4 \\
\hline Bulkheads & 2 & 1 & 0 & 3 \\
\hline $\begin{array}{l}\text { Passenger } \\
\text { seats }\end{array}$ & 1 & 1 & 1 & 3 \\
\hline $\begin{array}{l}\text { Anti-climber } \\
\text { (override) }\end{array}$ & 0 & 2 & 0 & 2 \\
\hline Windows & 2 & 0 & 0 & 2 \\
\hline $\begin{array}{l}\text { Crash energy } \\
\text { management }\end{array}$ & 0 & 1 & 0 & 1 \\
\hline End strength & 0 & 1 & 0 & 1 \\
\hline Floor strength & 1 & 0 & 0 & 1 \\
\hline $\begin{array}{l}\text { Panels and } \\
\text { flooring }\end{array}$ & 1 & 0 & 0 & 1 \\
\hline $\begin{array}{l}\text { Panels/carbody } \\
\text { end caps }\end{array}$ & 0 & 1 & 0 & 1 \\
\hline Side strength & 0 & 1 & 0 & 1 \\
\hline $\begin{array}{l}\text { Truck } \\
\text { attachment }\end{array}$ & 0 & 1 & 0 & 1 \\
\hline \hline Total & $\mathbf{3 4}$ & $\mathbf{2 2}$ & $\mathbf{4}$ & $\mathbf{6 0}$ \\
\hline
\end{tabular}

Table 3 lists design changes intended to reduce risk. In numerous crashes certain train features appeared likely to cause an injury, but they did not. These features thus introduce risk. The design changes associated with rectifying these features and removing the risk appear in Table 3. In nine of the 23 crashes fixture retention was a risk. Fixture retention refers to loose equipment, in the galley or kitchen, loose chairs in sleeper cars, unlocked seat assemblies, and so on. Surprisingly, although loose equipment was found in nine of the crashes, it did not cause an injury. But because loose equipment poses a significant risk in a crash, the design change of securing it, fixture retention, was included. Inadequate emergency training was cited in three of the 23 crashes. Because it did not lead to an injury, it also appears in the risk table.

\begin{tabular}{|c|c|c|c|c|}
\hline $\begin{array}{l}\text { Design } \\
\text { Change }\end{array}$ & $\begin{array}{l}\text { Almost } \\
\text { Certain }\end{array}$ & Probable & Possible & Total \\
\hline $\begin{array}{l}\text { Fixture } \\
\text { retention }\end{array}$ & 1 & 8 & 0 & 9 \\
\hline Seats & 2 & 2 & 0 & 4 \\
\hline Training & 0 & 3 & 0 & 3 \\
\hline $\begin{array}{l}\text { Coupler } \\
\text { separation }\end{array}$ & 0 & 2 & 0 & 2 \\
\hline $\begin{array}{l}\text { End frame } \\
\text { strength }\end{array}$ & 0 & 2 & 0 & 2 \\
\hline $\begin{array}{l}\text { Floor } \\
\text { strength }\end{array}$ & 0 & 2 & 0 & 2 \\
\hline $\begin{array}{l}\text { Fuel tank } \\
\text { integrity }\end{array}$ & 2 & 0 & 0 & 2 \\
\hline Interior & 0 & 2 & 0 & 2 \\
\hline $\begin{array}{l}\text { Record } \\
\text { keeping }\end{array}$ & 0 & 2 & 0 & 2 \\
\hline $\begin{array}{l}\text { Side } \\
\text { strength }\end{array}$ & 1 & 1 & 0 & 2 \\
\hline $\begin{array}{l}\text { Bridge } \\
\text { abutments }\end{array}$ & 0 & 1 & 0 & 1 \\
\hline $\begin{array}{l}\text { Luggage } \\
\text { rack }\end{array}$ & 0 & 1 & 0 & 1 \\
\hline $\begin{array}{l}\text { Passenger } \\
\text { restraints }\end{array}$ & 0 & 1 & 0 & 1 \\
\hline $\begin{array}{l}\text { Roof } \\
\text { strength }\end{array}$ & 0 & 1 & 0 & 1 \\
\hline Tables & 0 & 1 & 0 & 1 \\
\hline Windows & 0 & 0 & 1 & 1 \\
\hline Total & 6 & 29 & 1 & 36 \\
\hline
\end{tabular}

\section{RECOMMENDATIONS}

Twenty-three commuter and inter-city passenger train accidents, which occurred over the past twenty years, have been analyzed. The analysis has assessed the potential effectiveness of alternative injury mitigation strategies. The strategies with the greatest potential to increase passenger safety are interior occupant protection (compartmentalization and padding), coupler integrity, CEM, end structure integrity, side structure integrity, and glazing system integrity. FRA is currently conducting research in most of these areas. Coupler integrity,

This material is declared a work of the U.S. Government and is not subject to copyright protection in the United States. Approved for public release; distribution is unlimited. 
interior appurtenance integrity, and crew training are not currently being researched.

Increased coupler integrity could keep trains together more effectively, keeping cars from uncoupling. This recommendation is based on several accidents, including the May 12, 2015 Philadelphia derailment [35]. In that accident, the lead locomotive uncoupled from the first passenger car. The first passenger car subsequently impacted several catenary poles, and was severely damaged. If the equipment had remained coupled, then the stronger locomotive may have sustained more of the impacts. Improved coupler integrity potentially may have also helped in other accidents, such as the April 18, 2002 Crescent City intercity train derailment [30] and in the December 1, 2013 Spuyten Duyvil derailment [29].

Narrowly speaking, crew training is not an equipment feature. However, performance of the crew is essential to the effective use of equipment features in rescuing passengers in the event of an accident. As examples, reports for the accidents in Kingman, AZ on August 9, 1997 [36] and in Flora, MS on April 6, 2004 [37] all cited crew training as in issue during the emergency evacuations.

Interior fixture retention appears to have increased the likelihood of injury in nine of the 23 accidents considered. Interior fixture retention refers to loose galley equipment, loose seat assemblies, unsecured tables and chairs, open oven doors, and so on. There was not sufficient information available to directly link particular loose equipment to particular passenger and crew injury. But because loose equipment appears to pose a significant risk in a crash, the design change of securing it, fixture retention, was included as a mitigation feature. Accidents that had loose fixtures included those in Kingman, AZ on August 9, 1997 [36]; and Flora, MS on April 6, 2004 [37]; and Crescent City, FL on April 18, 2002 [30].

\section{SUMMARY}

As part of its responsibilities for railroad safety, FRA conducts research on passenger rail equipment crashworthiness. Research efforts have often been initiated by FRA in the wake of particular accidents. Accident reviews associated with such studies on glazing integrity and side structure integrity led to a more broadly scoped review of past passenger train accidents. The purpose of this broader review was to identify if there are passenger equipment features currently not being studied that might be effective in mitigating accident consequences. Three such features were found: coupler integrity, interior appurtenance integrity, and crew training.

\section{ACKNOWLEDGMENTS}

This work was done as part of the Federal Railroad Administration's Equipment Safety Research Program. Jeff Gordon is the FRA's Program Manager and Kevin Kesler is the Chief, Equipment and Operating Practices Division, Office of Research and Development. The authors also acknowledge their Volpe Center colleague, Laura Sullivan, for her ongoing technical advice and support in the research discussed in this paper.

\section{REFERENCES}

[1]. Bing, A., "Collision Avoidance and Accident Survivability, Volume 1: Collision Threat," DOT/FRA/ORD-93-02.I, FRA, U.S. Department of Transportation, 1993.

[2]. 49 CFR Part 229, 234, 235, et al. Positive Train Control Systems; Final Rule, Federal Register, Vol. 75, No. 10, January 15, 2010.

[3]. Lacôte, F., Cléon, L.-M., Lagneau, H., Dannawi, M., Demonsant, E., Wiart, A., 1993, "Les Tolérances à la Collision Des Matérials Ferroviaires," Revue générale des chemin de fer, Gauthier-Villars.

[4]. Scholes, A., and Lewis, J., 1993, "Development of Crashworthiness for Railway Vehicle Structures", Proceedings of the Institute of Mechanical Engineers, Vol. 207 Part F: Journal of Rail and Rapid Transit.

[5]. Ohnishi, T., Kawakami, N., Sano, A., 1993, "Crashworthiness of Train," The International Conference on Speedup Technology for Railway and Maglev Vehicles, Vol. I, PS2-15, the Japanese Society of Mechanical Engineers (JSME).

[6]. Tyrell, D.C., Severson, K.J., Marquis, B.J., "Crashworthiness of Passenger Trains," U.S. Department of Transportation, DOT/FRA/ORD-97/10, 1998.

[7]. 49 CFR Part 216 et al., Passenger Equipment Safety Standards; Final Rule, Federal Register, Vol. 64, No. 91, May 12, 1999.

[8]. Tyrell, D., Gordon, J., "Crash Energy Management: An Overview of Federal Railroad Administration Research," TRNews, No. 286, May-June 2013, Transportation Research Board.

[9]. Tyrell, D., Strang, J., Hynes, R., Peacock, T., Lydon, B., Woodbury, C.A., Stastney, J., "Development of a Crash Energy Management Specification for Passenger Rail Equipment," Compendium of Papers, 86th Annual Meeting, Transportation Research Board, Paper No. 07-0080, January 2007.

[10].Carolan, M., Jacobsen, K., Llana, P., Severson, K., Perlman, B., and Tyrell, D. (eds). "Technical Criteria and Procedures for Evaluating the Crashworthiness and Occupant Protection Performance of Alternatively Designed Passenger Rail Equipment for Use in Tier I Service." U.S. Department of Transportation, DOT/FRA/ORD-11/22. October, 2011.

[11].Tyrell, D.C., Severson, K.J., Marquis, B.J., "Analysis of Occupant Protection Strategies in Train Collisions," American Society of Mechanical Engineers, AMD-Vol. 210, BED-Vol. 30, pp. 539-557, 1995.

[12].Tyrell, D., Severson, K.J., "Crashworthiness Testing of Amtrak's Traditional Coach Seat," U.S. Department of Transportation, DOT/FRA/ORD-96/08, October 1996.

[13].49 CFR Part 216, et al. Passenger Equipment Safety Standards; Proposed RuleFederal Register, Vol. 62, No. 184, Tuesday, September 23, 1997.

[14].Parent, D., Tyrell, D., Perlman, A.B., "Crashworthiness Analysis of the Placentia, CA Rail Collision," Proceedings of ICrash 2004, International Crashworthiness Conference, San Francisco, California, July 14-16, 2004. 
[15].APTA SS-C\&S-016-99, Standard for Passenger Seats in Passenger Rail Cars, The American Public Transportation Association, Washington, DC.

[16].APTA-SS-C\&S-018 - Fixed Workstation Tables in Passenger Rail Cars, February,2013, The American Public Transportation Association, Washington, DC.

[17].National Transportation Research Board, "Collision between Northern Indiana Commuter Transportation District Eastbound Train 7 and Westbound Train 12 Near Gary, Indiana, on January 18, 1993," NTSB/RAR-93/03, PB93-916304, December 7, 1993.

[18].Mayville, R.A.,Stringfellow, R.G., Rancatore, R.J., Hosmer, T.P., "Locomotive Crashworthiness Research, Volumes 5: Cab Car Crashworthiness Report," DOT/FRA/ORD-95/08.5, 1996.

[19].National Transportation Research Board, "Near Head-on Collision and Derailment of Two New Jersey Transit Commuter Trains Near Secaucus, New Jersey, on February 9, 1996," NTSB/RAR-97/01, PB97-916301, March 25, 1997.

[20].National Transportation Research Board, "Collision and Derailment of Maryland Rail Commuter MARC Train 286 and National Railroad Passenger Corporation AMTRAK Train 29 Near Silver Spings, Maryland, on February 16, 1996," NTSB/RAR-97/02, PB97-916302, July 3, 1997.

[21].Muhlanger, M., Llana, P., Tyrell, D. "Dynamic and QuasiStatic Grade Crossing Collision Tests," American Society of Mechanical Engineers, Paper No. JRC2009-63035, March 2009.

[22]. Code of Federal Regulations, Title 49, Appendix F to Part 238-Alternative Dynamic Performance Requirements for Front End Structures of Cab Cars and MU Locomotives. Federal Register, Vol. 75, No. 5, January 8, 2010.

[23].Llana, P., Stringfellow, R., Mayville, R., "Finite Element Analysis and Full-Scale Testing of Locomotive Crashworthy Components," American Society of Mechanical Engineers, Paper No. JRC2013-2546, April 2013.

[24].Jacobsen, K., Llana, P., Carolan, M., Sullivan, L., "Fuel Tank Integrity Research: Fuel Tank Analyses and Test Plans," Proceedings of the 2013 ASME/IEEE/ASCE Joint Rail Conference, JRC2013-2425, April 2013.

[25].Llana, P., Tyrell, D., Rakoczy, P., "Conventional Locomotive Coupling Tests: Test Requirements and Pre-test Analysis," American Society of Mechanical Engineers, Paper No. JRC2016-5817, April 2016.

[26].Severson, K., "Research and Development of a Safety Standard for Workstation Tables in the U.S.," 9th International Symposium on Passive Safety, Berlin, Germany, February 2013.

[27].Gordon, J., Llana, P., Severson, K., Tyrell, D., "Rail passenger Equipment Glazing Integrity Research," Transportation Research Board, January 2016.

[28].National Transportation Research Board, "HighwayRailroad Grade Crossing Collision, US Highway 95, Miriam, Nevada June 24, 2011," Accident Report NTSB/HAR-12/03, PB2013-103891, December 11, 2012.

[29].National Transportation Research Board, "Railroad Accident Brief: Metro-North Railroad Derailment,"
Accident No.: DCA14MR002, Bronx, New York: December 1, 2013, NTSB/RAB-14/12, October 24, 2014, Corrected Copy.

[30].National Transportation Research Board, "Derailment of Amtrak Auto Train P052-18 on the CSXT Railroad Near Crescent City, Florida April 18, 2002," NTSB/RAR-03/02, PB2003-916302, August 5, 2003.

[31].National Transportation Research Board, "Railroad Accident Brief," Accident No.DCA-01-MR-003, Nodaway, Iowa, NTSB/RAB-02/01, March 5, 2002.

[32].National Transportation Research Board, "Preliminary Report Highway HWY15MH006," Oxnard, CA, 2/24/2015, HWY15MH006, March 19, 2015.

[33].Ioannidis, J.P.A., "Why Most Published Research Findings Are False," PLoS Med 2(8): e124. doi: 10.1371 /journal.pmed.0020124, 2005.

[34].Parent, D., Tyrell, D., Jacobsen, K., Severson, K., "Crashworthiness Analysis of the January 26, 2005 Glendale, California Rail Collision," American Society of Mechanical Engineers, Paper No. JRC2011-56132, March 2011.

[35].National Transportation Research Board, "Preliminary Report: Railroad DCA15MR010," Philadelphia, PA, 5/12/2015, DCA15MR010, June 2, 2015.

[36].National Transportation Research Board, "Derailment of Amtrak Train 4, Southwest Chief, on the Burlington Northern Santa Fe Railway near Kingman, Arizona, August 9, 1997," NTSB/RAR-98/03, PB98-916303, August 31, 1998.

[37].National Transportation Research Board, "Derailment of Amtrak Train No. 58, City of New Orleans near Flora, Mississippi, April 6, 2004," NTSB/RAR-05/02, PB2005916302, July 26, 2005.

[38].National Transportation Research Board, "Collision of Metrolink Train 111 With Union Pacific Train LOF65-12 Chatsworth, California, September 12, 2008," NTSB/RAR10/01, PB2010-916301, January 21, 2010.

[39].National Transportation Research Board, "Preliminary Report: Highway-Railroad Grade Crossing Collision DCA15MR006," Valhalla, NY, 2/3/2015, DCA15MR006, January 23, 2015.

[40].Carolan, M., "Evaluation of Occupant Volume Strength in Conventional Passenger Railroad Equipment," Tufts University Master's Thesis, May 2008.

[41].Markos, S., Tsai, T., Bukowski, R., "Development of U.S. Passenger Train Fire Safety Standards," $28^{\text {th }}$ International Conference on Fire Safety, July 28, 1999.

[42].Markos, S., Pollard, J.K., "Passenger Train Emergency Systems: Review of Egress Variables and Egress Simulation Models," DOT/FRA/ORD-13/22, DOT-VNTSC-FRA-1204, April 2013.

\section{APPENDIX A: OVERVIEW OF ACCIDENTS}

Passenger train accidents occur under a wide range of circumstances. Despite this broad range of circumstances, three accident categories encompass most accidents and help group different train and wayside features that may mitigate accidents. The three accident categories are:

1. Collisions with another train

This material is declared a work of the U.S. Government and is not subject to copyright protection in the United States. Approved for public release; distribution is unlimited. 
2. Collisions with objects, such as at a grade-crossing

3. Single train events, such as a derailment

Train-to-train collisions include the commuter train-freight train collision in Chatsworth, California on September 12, 2008 [38]. In Chatsworth a commuter train collided with a freight train at a closing speed of $\sim 80 \mathrm{mph}$, fatally injuring twenty-five people and injuring more than 100 others. Derailments include the commuter train derailment in Spuyten Duyvil, New York on December 1, 2013, fatally injuring four people and injuring more than fifty others [29]. Grade-crossing accidents include the commuter-SUV collision in Valhalla, New York on February 3, 2015, which resulted in six fatally injured people, including the SUV driver, and thirteen severely injured people [39]. Table A1, Table A2, and Table A3 list the train-to-train, derailments, and grade-crossing crashes that were analyzed for this paper.

Table A1. Train to train collisions

\begin{tabular}{|l|l|}
\hline Location & Date \\
\hline Bourbonnais, Illinois & March 15, 1999 \\
\hline Bridgeport, Connecticut & May 17, 2013 \\
\hline Canton, Massachusetts & March 25, 2008 \\
\hline Chatsworth, California & September 12, 2008 \\
\hline Chicago, Illinois & November 30, 2007 \\
\hline Glendale, California & January 26, 2005 \\
\hline Placentia, California & April 23, 2002 \\
\hline Secaucus, New Jersey & February 10, 1996 \\
\hline Silver Spring Maryland & February 16, 1996 \\
\hline Syracuse, New York & February 5, 2001 \\
\hline
\end{tabular}

Table A2 Derailments

\begin{tabular}{|l|l|}
\hline Location & Date \\
\hline Chicago, Illinois & September 17, 2005 \\
\hline Crescent City, Florida & April 18, 2002 \\
\hline Flora, Mississippi & April 6, 2004 \\
\hline Kensington, Maryland & July 29, 2002 \\
\hline Kingman, Arizona & August 9, 1997 \\
\hline Lake City, South Carolina & August 21, 2000 \\
\hline Nodaway, Iowa & March 17, 2001 \\
\hline Philadelphia, Pennsylvania & May 12, 2015 \\
\hline Spuyten Duyvil, New York & December 1,2013 \\
\hline
\end{tabular}

\begin{tabular}{|c|c|}
\hline Location & Date \\
\hline Lovelock, Nevada & June 24, 2011 \\
\hline Oxnard, California & February 24, 2015 \\
\hline Portage, Indiana & Jun 18,1998 \\
\hline Valhalla, New York & February 3, 2015 \\
\hline
\end{tabular}

In train accidents passengers and crew members are injured in numerous ways. A common one involves the non-restrained passenger, who maintains the pre-crash speed of the train, impacting a rigid surface that has decelerated due to the crash. The resulting difference between the human's speed and the train's speed, the " $\Delta \mathrm{V}$ ", subjects the human to both concentrated forces at contact surfaces and high acceleration forces to the head, neck, spine, and internal organs. Different rigid surfaces seats, tables, bulkheads — present different hazards.
Large $\Delta \mathrm{Vs}$ and corresponding hazards also occur when a rail car rolls on its side. Passengers or crew who were seated or standing at the high side of the rolled car accelerate as they fall to the low side. Impacts against seats, windows, or luggage racks subject humans to large forces.

Rolled cars sometimes introduce another major hazard to passenger and crew safety: dislodged windows. When a window separates from a train that has rolled, passengers may be ejected from the rolled (or rolling) car. The harsh environment outside the car and the near certainty that other rail cars are approaching from the rear, either of which can kill or injure humans, make dislodged windows particularly dangerous.

\section{Example train collision}

A locomotive-led commuter train and locomotive-led freight train collided head-on in the Chatsworth district of Los Angeles, California, with each train initially travelling at more than $40 \mathrm{mph}$ [38]. Twenty-four passengers and one crew member were killed on the passenger train, and approximately 138 train occupants were injured, many severely. The operator of the locomotive and twenty-two passengers were fatally injured due to loss of survival space. During the accident, the front of the passenger locomotive was crushed such that the operator's cab was pushed back over the heavy equipment inside the locomotive, eliminating the survival space for the operator. Nearly simultaneously, the first passenger car broke into two pieces at the lead end gooseneck, and the leading portion telescoped into the trailing portion, eliminating the survival space for twenty-two passengers. Two passengers in the telescoped portion are known to have survived. Two passengers inside the trailing passenger cars suffered fatal injuries by being thrown into the lower stepwells and sustaining severe head trauma. Figure A1 is a post-accident photograph of the first passenger car.

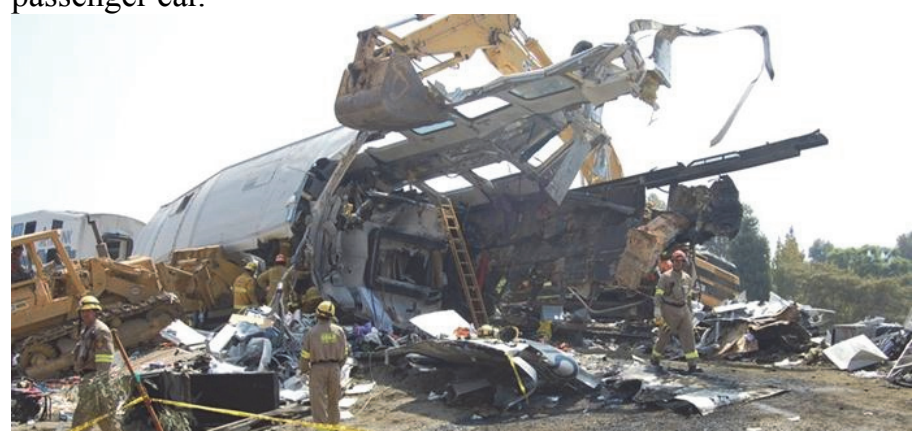

Figure A1. Post-collision Photographs of First Trailer Car, Passenger-to-Freight Train Collision, Chatsworth, CA

\section{Example grade-crossing accident}

Figure A2 shows a photograph of the colliding cab car and SUV, from the grade-crossing accident that occurred in Valhalla, New York on February 13, 2015 [39]. In that accident, a commuter train collided with an SUV, which was unable to clear crossing due to highway congestion when gates came down. The SUV picked up the third rail down the track from the crossing and threaded it into cab car, leading to fatal injuries and fire. All of the fatalities were associated with the third rail entering the cab car. There were no passengers fatally injured by the fire. The fire spread sufficiently slowly to allow surviving passengers to evacuate.

This material is declared a work of the U.S. Government and is not subject to copyright protection in the United States. Approved for public release; distribution is unlimited. 


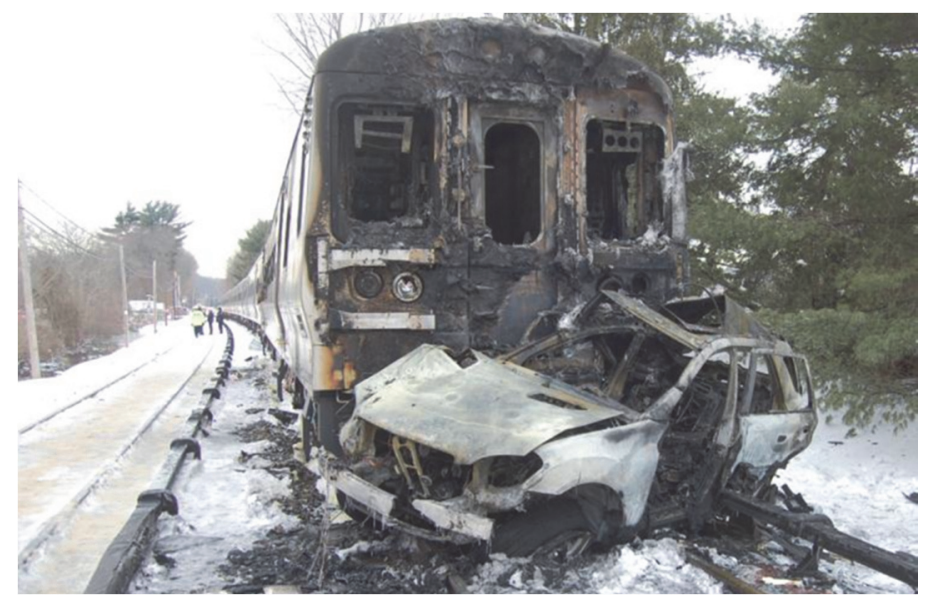

Figure A2. Photograph of Colliding Cab Car and SUV, Valhalla, New York, February 13, 2015.

\section{Example derailment}

On December 1, 2013, a Metro-North commuter train derailed just north of Spuyten Duyvil station in The Bronx [29]. Inbound train \#8808 consisted of a cab car, 6 trailer cars, and a locomotive. The train was in push-mode, approaching a $30 \mathrm{mph}$ curve at $82 \mathrm{mph}$, when it derailed. Four passengers died at the scene of the accident. The seven passenger cars and the locomotive all derailed during the accident. The leading four cars appeared to roll to the right further than others. Many windows on the right side of the train were broken, displaced, and/ or missing after the derailment and subsequent rollover. Significant amounts of dirt and ballast had accumulated in several of the cars. It appears that three fatally injured passengers were ejected from the train via window openings during the derailment. The bodies were located outside or under the train when first responders arrived. There is some uncertainty about where the fourth fatally injured passenger came to rest after the accident; the body had been moved before the coroner arrived on the scene. All train occupants that were contained within the cars survived the derailment. Figure A3 shows the right side of the leading cab car as it came to rest after the accident, with several windows dislodged.

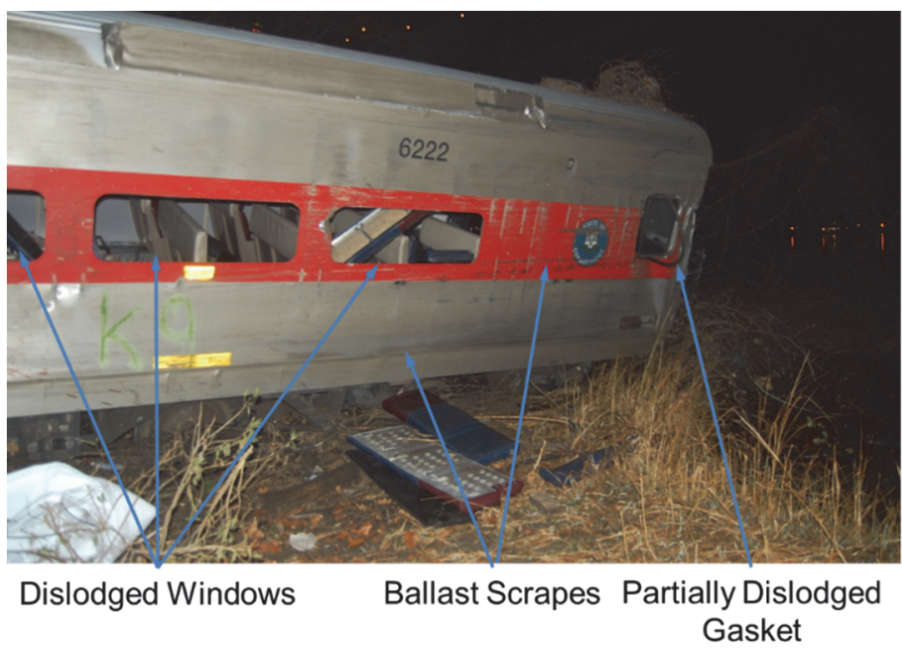

Figure A3. Photograph of Leading Cab Car, Spuyten Duyvil, New York, December 1, 2015.

\section{APPENDIX B: OVERVIEW OF INJURY MITIGATION STRATEGIES}

Four categories of injury-mitigation strategies have been considered: train crashworthiness, wayside structure crashworthiness, fire safety, and emergency preparedness. Train crashworthiness includes such strategies as interior occupant protection, coupler integrity, end structure integrity, side structure integrity, and glazing system integrity. Wayside structure crashworthiness includes strategies such as frangible catenary poles and third rail end caps. Fire safety includes train interior and train exterior strategies for minimizing the potential for fire and for reducing the rate at which fire might spread. Emergency preparedness includes strategies for emergency egress, access, lighting, signage, crew training, and on-board equipment, such as fire extinguishers.

\section{Train Crashworthiness}

The primary objectives of crashworthiness are to preserve space for occupants to ride out the accident and to limit to survivable levels the forces imparted to occupants. These objectives are pursued with structural crashworthiness and interior occupant protection.

\section{Structural Crashworthiness}

As shown in Table B1, the structural crashworthiness mitigation category can be divided into three subcategories: carbody integrity, crash energy management (CEM), and exterior appurtenance integrity. Carbody integrity is oriented toward providing space for the occupants and keeping the occupants contained during an accident. CEM is oriented toward managing the load path and load magnitude applied to the carbody structure, i.e., inhibiting car-to-car override and lateral buckling. CEM relies on occupant volume integrity to support equipment features such as pushback couplers, deformable anticlimbers, and primary energy absorbers. Exterior appurtenance integrity is oriented toward minimizing potential threats posed by any external equipment, such as damage from subsequent collisions with a truck that has broken free from a car.

Table B1. Structural Crashworthiness Features

\begin{tabular}{|l|l|}
\hline Subcategory & Equipment Feature \\
\hline \multirow{4}{*}{ Carbody Integrity } & End strength \\
\cline { 2 - 2 } & End frame integrity \\
\cline { 2 - 2 } & Glazing integrity \\
\cline { 2 - 2 } & Roof strength \\
\cline { 2 - 2 } & Floor strength \\
\cline { 2 - 2 } Manh Energy & Side strength \\
\hline \multirow{2}{*}{$\begin{array}{l}\text { Exterior Appurtenance } \\
\text { Integrity }\end{array}$} & Pushback coupler \\
\cline { 2 - 2 } & Deformable anti-climber \\
\cline { 2 - 2 } & Primary energy absorber \\
\cline { 2 - 2 } & Fuel tank integrity \\
\cline { 2 - 2 } & Truck attachment \\
\cline { 2 - 2 } & Coupler integrity \\
\hline
\end{tabular}

Figure B1 schematically illustrates all of the carbody integrity features. Carbody integrity provides a strong space, to preserve space for occupants to ride out an accident without being crushed. End strength, an underframe characteristic, 
provides the foundation for all of the other features: end structure, side structure, and roof.

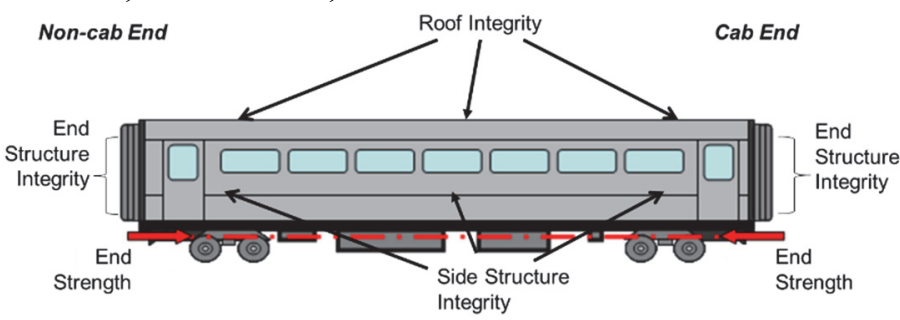

Figure B1. Schematic Illustration of Carbody Integrity Features.

The traditional railroad approach to crashworthiness is to build a strong underframe, which can sustain a high buff load without permanent deformation [40]. CEM adds features which manage the load path, to inhibit both override of colliding and coupled equipment and lateral buckling. These features help assure that the strong underframe is loaded in a favorable manner, so that it can sustain a high longitudinal load throughout a train-to-train collision. By loading the underframe this way, such features also help inhibit crippling and collapse of the underframe. Energy absorbing features are used at the ends of cars also help assure that structural deformation is appropriately distributed and not catastrophically focused on one piece of equipment. FRA has directed research on Crash Energy Management, including detailed computer simulations and fullscale tests of rail cars and trains [8]. Figure B2 shows extracted stills of the colliding cab car and locomotive from high speed video from the train-to-train tests of conventional and CEM equipment. In the test of conventional equipment the cab car overrode the locomotive, resulting in loss of occupant volume. In the test of CEM equipment the cab car remained engaged with the locomotive, preserving the occupant volume.

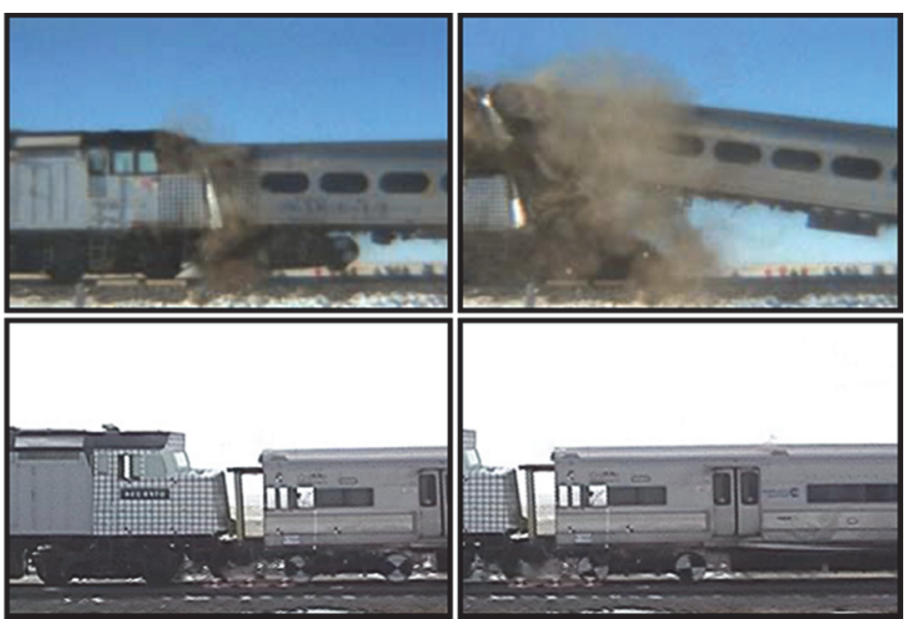

Figure B2. Extracted Stills from High Speed Video from Conventional and CEN Train-to-Train Collision Tests.

\section{Interior Occupant Protection}

Interior occupant protection has been divided into two categories, as shown in Table B2. Compartmentalization is oriented toward containing occupants within a limited space and providing deformable surfaces which limit the forces imparted to occupants [11]. Interior appurtenance integrity is oriented towards preventing tertiary impacts, e.g., keeping occupants from being impacted by projectiles such as flying luggage or interior appurtenances that have broken free.

Table B2. Interior Occupant Protection Features

\begin{tabular}{|l|l|}
\hline Subcategory & Interior Feature \\
\hline \multirow{4}{*}{ Compartmentalization } & Seats \\
\cline { 2 - 2 } & Tables \\
\cline { 2 - 2 } Interior Appurtenance & Bulkheads \\
\hline \multirow{2}{*}{ Integrity } & Luggage racks \\
\cline { 2 - 2 } & $\begin{array}{l}\text { Fixture retention, e.g., } \\
\text { galley equipment }\end{array}$ \\
\hline
\end{tabular}

Judicious placement of the impact surface can be effective in reducing injuries. By placing the seats reasonably close together, the distance the occupant travels before the secondary impact can be minimized. The occupant will have less distance in which to build up speed relative to the occupant compartment. For example, in the seats in rows configuration, the occupant has less than 3 feet to travel before impacting the forward seat back. Therefore, the impact velocity relative to the train will be reduced as the travel distance is reduced, resulting in less severe impacts. In the seats and table configuration, the table acts to arrest the occupant's motion before higher velocities can be attained. Provided the table edges are sufficiently blunt (so as not to impart severely concentrated forces on the occupant's abdomen), this also can be an effective compartmentalization strategy. Figure B3 shows the kinematics of an occupant, initially seated in rows of seats during a train collision. The occupant is contained by the seat ahead. The back of the seat ahead deforms sufficiently to absorb energy and limit the forces imparted to survivable levels.

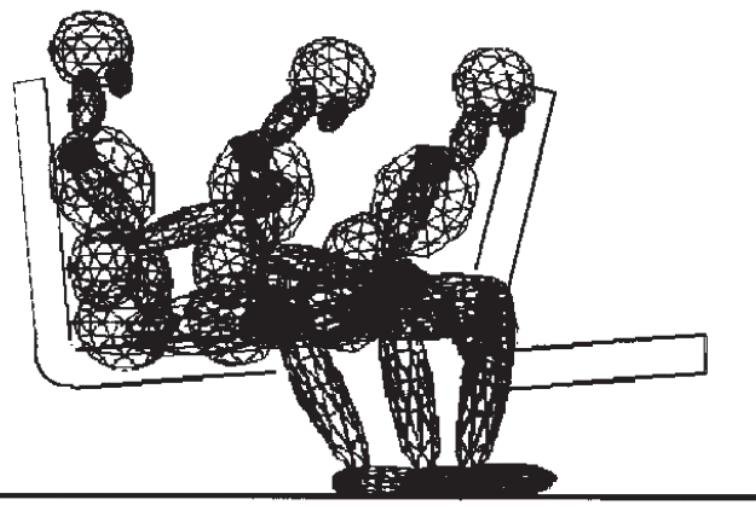

Figure B3. Computer Simulation Results, Occupant Compartmentalized in Rows of Seats during a Train-totrain Collision.

\section{Wayside Structure Crashworthiness}

Wayside structure crashworthiness has the goals of limiting both the magnitude of loads imparted to the rail equipment and the location of load application to the equipment. Frangible structures, similar to break-away light poles used on U.S. interstate highways, have the potential to minimize damage during a derailment. End caps on third rails have the potential to limit where loads are applied to passenger rail equipment during accidents. Table B3 lists the wayside structures that may benefit from crashworthiness features.

This material is declared a work of the U.S. Government and is not subject to copyright protection in the United States. Approved for public release; distribution is unlimited. 
Table B3. Wayside Structure Crashworthiness Features

\begin{tabular}{|l|l|}
\hline Subcategory & Wayside Structure \\
\hline \multirow{2}{*}{ Frangible Structures } & Catenary poles \\
\cline { 2 - 2 } & Bridge abutments \\
\hline Protected Structures & Third rail end cap \\
\hline
\end{tabular}

\section{Fire Safety}

The goal of rail equipment fire safety is to inhibit the spread of fire sufficiently to allow the passengers and crew sufficient time to safely exit the train. In other words, the goal is not to prevent fire completely, but to assure that it spreads very slowly. Fires can start either inside or outside a train, and may spread from one to the other. Table B4 lists interior and exterior rail equipment fire safety features that may benefit from improved fire inhibition.

Table B4. Rail Equipment Fire Safety Features

\begin{tabular}{|l|l|}
\hline Subcategory & Design Change \\
\hline \multirow{2}{*}{ Exterior } & Panels/carbody end caps \\
\cline { 2 - 2 } & Windows \\
\hline \multirow{2}{*}{ Interior } & Panels and flooring \\
\cline { 2 - 2 } & Seats \\
\hline
\end{tabular}

FRA has conducted fire safety research, and the results have been used to develop current FRA regulations [41]. The accident review done for this paper indicates that the regulations and associated industry practices are largely effective in mitigating the consequences of fire.

\section{Emergency Preparedness.}

Passenger rail equipment emergency preparedness features are used by both the train occupants and emergency responders. The primary goals of emergency preparedness features on rail passenger equipment are to allow occupants to quickly exit the train without the need for assistance and to allow emergency responders rapid entry. Table B5 lists emergency preparedness features categorized according to crew preparation, equipment interior, and equipment exterior.

Table B5. Emergency Preparedness Features

\begin{tabular}{|l|l|}
\hline Subcategory & Feature \\
\hline \multirow{2}{*}{ Crew Preparation } & Record keeping \\
\cline { 2 - 2 } & Training \\
\hline \multirow{3}{*}{ Equipment Interior } & Egress \\
\cline { 2 - 2 } & Lighting \\
\cline { 2 - 2 } Equipment Exterior & Signage \\
\hline & Access \\
\cline { 2 - 2 } & Signage \\
\hline
\end{tabular}

These features need to work hand-in-hand with other equipment safety features. So fire safety features are relied upon to slow down the spread of fire, while emergency preparedness features allow exiting the train before the fire has spread sufficiently to be life-threatening.

Perhaps most critically, the passenger equipment emergency features must effectively facilitate emergency response. Such equipment features should fit seamlessly within the broader considerations of the railroads emergency response plans. Ideally, training of emergency responders, so that they are familiar with these features before an accident occurs, is part of passenger railroads emergency response plans and preparation.

FRA has conducted emergency preparedness research, and the results have been used to develop current FRA regulations [42]. The accident review done for this paper indicates that the equipment regulations and associated industry practices are largely effective in mitigating the consequences of fire. The review results, however, suggest potential improvements may be found in increased crew training and preparation for coping with emergencies. 